\title{
PERBANDINGAN KADAR KALSIUM PADA IBU BERSALIN \\ NORMATENSI DENGAN PREEKLAMPSIA BERAT (PEB) \\ DI RUANG VK RS SMC TASIKMALAYA TAHUN 2018
}

\author{
Ingelda Soraya $^{1}$, Nunung Mulyani APP ${ }^{2}$, Qanita Wulandara ${ }^{3}$ \\ (ingeldasoraya81@gmail.com)
}

\section{A. ABSTRAK}

Pada masa kehamilan terjadi peningkatan kebutuhan kalsium yang akan diserap oleh janin sehingga diperlukan keseimbangan kadar kalsium untuk perkembangan janin dan kebutuhan metabolisme ibu serta pencegahan tekanan darah tinggi. Pada kehamilan normatensi, keadaan kadar kalsium lebih tinggi bila dibandingkan dengan pada kehamilan preeklampsia. Tujuan penelitian ini untuk mengetahui perbedaan kadar kalsium pada ibu bersalin normatensi dengan ibu bersalin PEB di Ruang VK RS SMC Tasikmalaya.

Jenis penelitian yang digunakan dalam penelitian ini adalah studi komparatif, karena dengan menggunakan metode ini dapat mencari perbedaan pada dua kelompok yang berbeda yaitu kadar kalsium pada ibu bersalin normal dan PEB. Sampel adalah ibu bersalin yang datang ke ruang VK di RS SMC Kabupaten Tasikmalaya pada bulan November tahun 2018 sebanyak 48 orang yang diperoleh dengan teknik accidental sampling. Data diperoleh dengan menggunakan Format isian kemudian dianalisis dengan uji indepent sampel T tes.

Hasil penelitian diperoleh kadar kalsium pada ibu bersalin normatensi sebagian besar termasuk normal (91.7\%). Sedangkan kadar kalsium pada ibu bersalin dengan PEB sebagian tidak normal (90.3\%). Hasil uji statistik diperoleh terdapat perbedaan kadar kalsium pada ibu bersalin normatensi dengan ibu bersalin PEB di Ruang VK RS SMC Tasikmalaya 2018 dengan p value 0,000.

Kesimpulan dari penelitian ini adalah terdapat perbedaan kadar kalsium pada ibu bersalin normatensi dengan ibu bersalin PEB. Oleh karena itu, bidan dapat memberikan asuhan kebidanan dalam rangka mencegah komplikasi kebidanan dengan memberikan asupan kalsium pada ibu hamil.

Kata Kunci : $\quad$ Kalsium, Normatensi, PEB

\section{B. PENDAHULUAN}

Preeklampsia merupakan suatu keadaan tekanan darah tinggi yang disertai dengan protein urine. Sepuluh juta wanita mengalami preeklamsia setiap tahun di seluruh dunia. Kasus preeklamsia di seluruh dunia sekitar 76.000 wanita hamil yang meninggal setiap tahun oleh karena preeklamsia dan gangguan hipertensi pada kehamilan lainnya, dan jumlah bayi yang meninggal karena gangguan ini sekitar 500.000 per tahun. Setiap tahun hampir 40000 wanita terutama di negara berkembang meninggal oleh karena preeklamsia atau eklamsia.

Preeklampsia di Indonesia menjadi salah satu penyebab kematian ibu, menurut hasil Survei Demografi Kesehatan Indonesia AKB di 
Indonesia pada tahun 2012 mencapai 32/1000 kelahiran hidup dan AKI mencapai kisaran 359/100.000 kelahiran hidup, hal ini mengalami penurunan bila dibandingkan AKI pada tahun 2015 mencapai 305/100. 000 kelahiran hidup (Kemenkes, 2017).

Masih tingginya angka kematian ibu, maka negara-negara di dunia mencanangkan Sustainable Development Goals (SDGs) sebagai program dunia dimana pada tahun 2016 sampai 2030 dalam menurunkan angka kematian dan kesakitan. SDGs tidak lain merupakan kelanjutan dari targettarget MDGs dalam hal memprioritaskan upaya peningkatan derajat kesehatan ibu dan anak (KIA) dengan indikator pada kematian di negara maju, negara berkembang dan negara miskin (Hoelman, 2015).

Adanya peningkatan angka kematian ibu selama tiga tahun terakhir menurut kemenkes RI (2017) disebutkan bahwa penyebab kematian ibu langsung adalah sebagai akibat komplikasi kehamilan, persalinan atau masa nifas seperti preklampsia (25\%), perdarahan $(19,3 \%$ biasanya perdarahan postpartum), infeksi (15\%), partus macet $(8 \%)$, komplikasi abortus (13\%) dan sebab lain $(8 \%)$.

Melihat dari penyebab kematian ibu tersebut, preeklampsia atau Hipertensi dalam kehamilan (HDK) menyumbangkan angka kematian ibu tertinggi di Indonesia. Hal ini dukung dengan kasus preeklampsia di provinsi Jawa Barat masih cukup tinggi, dimana kasus preeklampsia pada tahun 2017 mencapai 695 kasus dari 4167 total kasus kematian ibu di Indonesia (Dinkes Jabar, 2017).

Tingginya angka kejadian preeklamsia dan eklamsia menyebabkan pentingnya untuk deteksi dini terutama kejadian eklamsia yang menimbulkan morbiditas dan mortalitas maternal dan perinatal yang lebih buruk. Preeklamsia atau eklamsia merupakan kausa utama kedua terjadinya kematian maternal dikarenakan kekurangan asupan kalsium yang ditemukan pada sebagian besar kasus studi yang berhubungan dengan hipertensi dalam kehamilan. Etiologi pasti tidak diketahui, namun ada kaitannya dengan perubahan dalam status elektrolit. Elektrolit seperti Kalsium $(\mathrm{Ca} 2+)$, Magnesium $(\mathrm{Mg} 2+)$, Natrium $(\mathrm{Na}+)$, dan Kalium $(\mathrm{K}+)$ memainkan peran penting dalam preeklamsia dan eklamsia karena mereka memberikan kontribusi yang signifikan dalam fungsi otot polos vascular.

Kalsium merupakan faktor predisposisi pertama kali disebutkan pada tahun 1980. Pada suku Indian maya di amerika selatan yang mendapatkan asupan kalsium tinggi dari jeruk nipis, memiliki insidensi preeklamsia yang rendah. Wanita dengan asupan kalsium yang rendah memiliki peningkatan rata-rata tekanan darah, yang menjadi predisposisi terjadinya preeklamsia (Benson, 2009).

Para ahli mengajukan hipotesis yang menyatakan bahwa defisiensi/kekurangan kalsium merupakan salah satu penyebab terjadinya preeklampsia / eklampsia. Kadar kalsium penderita preeklampsia diduga rendah sehingga berakibat kadar kalsium intraseluler meningkat. Dengan meningkatnya kalsium intraseluler maka pembuluh darah mudah mengalami vasokonstriksi yang akhirnya berakibat meningkatnya tekanan darah (Prawihardjo, 2008)

Beberapa studi melakukan penelitian asupan kalsium pada kehamilan normal dan kehamilan dengan komplikasi. Korelasi antara asupan kalsium, kadar plasma kalsium, dan insidensi dari preeklamsia telah diteliti. Manfaat potensial yang didapat pada suplemen kalsium selama kehamilan yang menurunkan preeklamsia, telah banyak digali. Perubahan fungsi vaskuler memainkan 
peran penting dalam kontrol resistensi vaskuler dan tekanan darah.

Dalam masa kehamilan terjadi peningkatan kebutuhan kalsium. Janin memerlukan $300 \mathrm{mg}$ kalsium perhari pada akhir kehamilan. Ketika hamil maka kebutuhan kalsium untuk gizi ibu hamil menjadi $1.200 \mathrm{mg}$ kalsium per hari. Cukup signifikan bukan perbedaan angka kebutuhan kalsium saat tidak hamil dan ketika hamil.

Hormon paratiroid berperan meningkatkan absorbsi kalsium di usus untuk memenuhi kebutuhan tersebut. Pada saat kehamilan kadar kalsium dalam serum akan menurun namun kadar kalsium yang terionisasi tidak berubah. Nilai normal kadar kalsium adalah sebagai berikut: kalsium total 8,9-10,9 mg/dL (2,2-2,5 mmol/L), Nilai untuk kalsium total dibawah $8,9 \mathrm{mg} / \mathrm{dL}$ $(2,2 \mathrm{mmol} / \mathrm{L})$ menunjukkan hipokalsemia dan nilai diatas 10,1 $\mathrm{mg} / \mathrm{dL} \quad(2,5 \mathrm{mmol} / \mathrm{L})$ menunjukkan hiperkalsemia. Selama kehamilan kekurangan asupan $\mathrm{Ca}$ akan mengakibatkan penurunan kadar $\mathrm{Ca} 2+$ plasma dan penurunan aliran darah uteri, kenaikan tekanan darah dan peningkatan protein urin: semua symptom tersebut ada pada PEB (Jembawan 2015).

Helga (2016) dalam penelitiannya menunjukkan terdapat perbedaan rerata rasio kalsium magnesium dan rasio natrium kalium antara kedua kelompok dianalisis menggunakan uji t independent. Rerata rasio kalsium magnesium pada PEB lebih tinggi secara bermakna dibandingkan eklamsia dan rerata rasio natrium kalium pada PEB lebih rendah secara bermakna dibandingkan eklamsia dengan $p$ value 0,000 .

Rumah Sakit SMC merupakan salah satu rumah sakit di Kabupaten Tasikmalaya, dari data yang diperoleh di Ruang VK pada tahun 2017 didapatkan jumlah ibu bersalin dengan sectio caesaria (SC) mencapai 433 kasus, sedangkan persalinan pervaginam mencapai 917 orang. Dari ibu bersalin tersebut sebanyak 172 kasus persalinan dengan PEB, kemudian pada tahun 2018 periode Januari sampai Agustus kasus ibu bersalin PEB mencapai 291 kasus.

Berdasarkan uraian tersebut, maka penulis tertarik untuk melakukan penelitian mengenai perbedaan kadar kalsium pada ibu bersalin normatensi dengan ibu bersalin PEB di Ruang VK RS SMC Tasikmalaya.

\section{METODOLOGI PENELITIAN}

Penelitian ini dilaksanakan di RS SMC Kabupaten Tasikmalaya, di ruang bersalin (VK) pada bulan November 2018. Populasi dalam penelitian ini adalah semua ibu bersalin yang datang ke ruang VK di RS SMC Kabupaten Tasikmalaya pada bulan November tahun 2018. Sampel dipilih berdasarkan purposive sampling dari ibu bersalin

Kriteria Inklusi

1. Ibu bersalin tidak memiliki komplikasi lain seperti anemi, diabetes

2. Bersedia menjadi responden

3. Pasien dengan menggunakan Jaminan Kesehatan (BPJS/ Jampersal)

Kriteria eksklusi

4. Ibu dengan kehamilan kembar

5. Memiliki riwayat hipertensi kronik dan hipertensi gestasional

Setelah dilakukan penelitian, jumlah sample yang memenuhi kriteria inklusi dan eksklusi sebanyak 48 orang.

Jenis penelitian yang digunakan dalam penelitian ini adalah studi komparatif, karena dengan menggunakan metode ini dapat mencari perbedaan pada dua kelompok yang berbeda yaitu kadar kalsium pada ibu bersalin normal dan PEB

Teknik pengumpulan data dalam penelitian ini menggunakan metode kuantitatif, teknik pengumpulan data dengan cara menentukan sampel penelitian 
dengan melihat jumlah ibu bersalin yang datang ke PONEK, kemudian melakukan pemeriksaan rutin mengenai tekanan darah, dan pemeriksaan laboratorium. Dapat diidentifikasi normotensi atau PEB, dan dari hasil pemeriksaan laboratorium dapat

\section{HASIL PENELITIAN}

1. Kadar kalsium pada ibu bersalin normatensi

Tabel Kadar kalsium pada ibu bersalin normatensi di Ruang VK RS SMC Tasikmalaya 2018

\begin{tabular}{llllll}
\hline & N & Min & Maks & Rata-rata & Simp. Baku \\
\hline $\begin{array}{l}\text { Kadar } \\
\text { Kalsium }\end{array}$ & 48 & 4.0 & 5.6 & 4.833 & 0.288 \\
\hline
\end{tabular}

Bahwa kadar kalsium pada ibu bersalin normatensi paling rendah adalah $4.0 \mathrm{gr} / \mathrm{dl}$, paling tinggi $5.6 \mathrm{gr} / \mathrm{dl}$. Rata-rata kadar kalsium pada ibu bersalin normatensi sebesar $4.83 \mathrm{gr} / \mathrm{dl}$ dengan standar deviasi $0.28 \mathrm{gr} / \mathrm{dl}$.

2. Kadar kalsium pada ibu bersalin dengan PEB

Tabel Kadar kalsium pada ibu bersalin dengan PEB

di Ruang VK RS SMC Tasikmalaya 2018

\begin{tabular}{llllll}
\hline & N & Min & Maks & Rata-rata & Simp. Baku \\
\hline Kadar Kalsium & 31 & 3.0 & 4.6 & 3.91 & 0.436 \\
\hline
\end{tabular}

Kadar kalsium pada ibu bersalin PEB paling rendah adalah $3.0 \mathrm{gr} / \mathrm{dl}$, paling tinggi 4.6 gr/dl. Rata-rata kadar kalsium pada ibu bersalin normatensi sebesar 5.24 gr/dl dengan standar deviasi $7.57 \mathrm{gr} / \mathrm{dl}$.

3. Perbedaan kadar kalsium pada ibu bersalin normatensi dengan ibu bersalin PEB

Tabel Perbedaan kadar kalsium pada ibu bersalin normatensi dengan ibu bersalin PEB di Ruang VK RS SMC Tasikmalaya 2018.

\begin{tabular}{lllllll}
\hline & TD & N & Mean & D & Thitung $_{\text {n }}$ & P value \\
\hline $\begin{array}{l}\text { Kadar } \\
\text { kalsium }\end{array}$ & Normatensi & 48 & 4.833 & 0,923 & 11,333 & 0,004 \\
\cline { 2 - 5 } & PEB & 31 & 3.910 & & & \\
\hline
\end{tabular}

Rata-rata kadar kalsium pada ibu bersalin normatensi sebesar $4.833 \mathrm{gr} / \mathrm{dl}$, sedangkan pada rata-rata kadar kalsium pada ibu bersalin PEB sebesar 3.910. sehingga terdapat perbedaan rata-rata kadar kalsium sebesar 0.923. Hasil uji statistik menggunakan uji independent sampel $T$ test didapatkan $\mathrm{p}$ value $0,004(<0,05)$ artinya terdapat perbedaan kadar kalsium pada ibu 
bersalin normatensi dengan ibu bersalin PEB di Ruang VK RS SMC Tasikmalaya 2018.

\section{E. PEMBAHASAN}

\section{Kadar kalsium pada ibu bersalin normatensi}

Hasil penelitian didapatkan kadar kalsium pada ibu bersalin normatensi paling rendah adalah $4.0 \mathrm{gr} / \mathrm{dl}$, paling tinggi $5.6 \mathrm{gr} / \mathrm{dl}$. Rata-rata kadar kalsium pada ibu bersalin normatensi sebesar $4.83 \mathrm{gr} / \mathrm{dl}$ dengan standar deviasi 0.28 gr/dl. Melihat dari data tersebut mengindikasikan bahwa kebutuhan kadar kalsium pada bersalin dapat terpenuhi. Karena memang kalsium memegang peranan penting dalam berbagai proses fungsi fisiologis didalam tubuh yaitu proses pembekuan darah, bersama dengan natrium dan kalium mempertahankan potensial membran, tranduksi sinyal antara reseptor hormon, Eksitabilitas neuromuskuler, integritas membran sel, reaksi-reaksi enzymatik, proses neurotranmisi, membentuk struktur tulang dan sebagai cadangan kalsium tubuh (John MF, 2009).

Pada penelitian ini keadaan kalsium rendah didapatkan juga pada ibu bersalin normatensi. Hal ini disebabkan karena proses hemodilusi, sekresi urin yang meningkat, transfer mineral kalsium dari ibu ke janin yang meningkat serta intake rendah kalsium pada ibu hamil. Metabolisme atau absorbsi kalsium pada ibu hamil akan meningkat terutama pada trimester kedua dan ketiga, peningkatan absorbsi ini berhubungan dengan intake kalsium pada ibu.

Berdasarkan uraian tersebut dapat dikemukakan bahwa kadar kalsium pada ibu bersalin normatensi adalah berkisar antara 4.5-5.6 gr/dl. Artinya pada kondisi tekanan darah yang normal, maka kadar kalsium akan mendekati nilai normal pada orang dewasa. Kalsium cukup selama kehamilan disebabkan asupan kalsium khususnya dalam vitamin D terpenuhi selama kehamilan.

\section{Kadar kalsium pada ibu bersalin dengan PEB}

Berdasarkan hasil penelitain didapatkan bahwa kadar kalsium pada ibu bersalin PEB paling rendah adalah $3.0 \mathrm{gr} / \mathrm{dl}$, paling tinggi $4.6 \mathrm{gr} / \mathrm{dl}$. Ratarata kadar kalsium pada ibu bersalin normatensi sebesar $3.91 \mathrm{gr} / \mathrm{dl}$ dengan standar deviasi $0.436 \mathrm{gr} / \mathrm{dl}$.

Data tersebut mengindikasikan keadaan kadar kalsium pada ibu bersalin PEB adalah kurang dari $4.5 \mathrm{gr} / \mathrm{dl}$. Artinya pada kondisi tekanan darah tinggi, maka kadar kalsium akan semakin rendah. Kalsium yang rendah penyebab tekanan darah tinggi yang dipicu oleh pelepasan hormon paratiroid atau renin yang menyebabkan peningkatan kalsium intraseluler pada vascular smooth muscle dan memicu vasokontriksi.

Aksi dari suplemen kalsium menurunkan pelepasan paratiroid dan intraseluler kalsium dan menyebabkan penurunan kontraktilitas smooth muscle. Dengan mekanisme yang sama suplemen kalsium juga menurunkan kontraksi smooth muscle uterus dan mencegah kelahiran preterm serta persalinan.

Oleh sebab itu selama kehamilan apabila terjadi penurunan kadar kalsium karena penyerapan kadar kalsium oleh janin sehingga menyebabkan penurunan kadar kalsium pada ibu hamil. Apabila terjadi kekurangan kadar kalsium pada ibu hamil akan mempengaruhi fungsi vaskuler sehingga mengalami vasokontriksi akibat defisiensi kadar kalsium sehingga meningkatkan tekanan darah dapat mengakibatkan preeklamsi berat. 


\section{Perbedaan kadar kalsium pada ibu bersalin normatensi dengan ibu bersalin PEB}

Hasil penelitian didapatkan bahwa rata-rata kadar kalsium pada ibu bersalin normatensi sebesar $4.833 \mathrm{gr} / \mathrm{dl}$, sedangkan pada rata-rata kadar kalsium pada ibu bersalin PEB sebesar 3.910. sehingga terdapat perbedaan rata-rata kadar kalsium sebesar 0.923 .

Melihat dari data tersebut menunjukkan ibu bersalin yang mengalami PEB lebih cenderung mengalami kadar kalsium yang tidak normal dibandingkan dengan ibu bersalin yang normatensi. Hal ini diperkuat dengan hasil uji statistik menggunakan uji independent sampel $T$ test didapatkan $\mathrm{p}$ value $0,004(<0,05)$ artinya terdapat perbedaan kadar kalsium pada ibu bersalin normatensi dengan ibu bersalin PEB di Ruang VK RS SMC Tasikmalaya 2018.

Menurut analisis peneliti adanya kadar kalsium yang rendah pada ibu hamil dengan preeklamsia berat mengindikasikan asupan atau absorpsi kalsium berbeda sehingga dapat meningkatkan kasus preeklampsia. Artinya keterlibatan mineral seperti kalsium dalam patogenesis preeklamsia. Oleh karena itu kalsium sangat diperlukan untuk perkembangan kehamilan yang normal dan menjaga fungsi tubuh. Kalsium diperlukan untuk berbagai macam proses penting seperti eksitabilitas neuron, pelepasan neurotransmitter, kontraksi otot, integritas membran dan pembekuan darah.

Kadar kalsium pada kelompok bersalin normotensi termasuk dalam rentang normal karena diketahui kadar kalsium normal yaitu adalah 4,5-5,6 gr/dL. Rata-rata kadar kalsium darah paling rendah dijumpai pada kelompok PEB yaitu 3.0 gr/dl. Hasil juga menggambarkan semakin tinggi tekanan darah, semakin rendah kadar kalsium darahnya. Hal ini sesuai dengan penelitian yang juga melaporkan kadar kalsium darah kelompok PEB paling rendah dibandingkan kelompok normotensi.

Hasil penelitian ini sesuai dengan penelitian lain yang melaporkan adanya kadar kalsium yang rendah pada ibu hamil dengan preeklamsia dibandingkan ibu hamil yang tidak preeklamsia Preeklamsia mempunyai patogenesis yang kompleks (Zapata, 2013).

Hasil penelitian yang dilakukan oleh Harini (2018) menemukan bahwa rata-rata kadar kalsium darah pada kelompok PEB paling rendah $(3,34 \mathrm{mg} / \mathrm{dL})$ dan berbeda bermakna secara statitstik dibandingkan kelompok PER (3,79mg/dL) dan normotensi (4,71). Penelitian ini menunjukkan bahwa potensi preeklampsia berat memiliki kadar kalsium lebih rendah dibandingkan dengan kehamilan normatensi.

Sebuah penelitian melaporkan adanya keterlibatan Human Leukocyte Antigen-C (HLA-C) dan Natural Killer cell (sel NK) dalam proses terjadinya preeklamsia (19). Penelitian lain melaporkan peran sitokin inflamasi khususnya tumor Necrosis Factor- $\alpha$ (TNF- $\alpha$ ) dalam menimbulkan gejala preeklamsia (Agmar, 2016). Banyak penelitian yang melaporkan keterlibatan mineral seperti kalsium dalam patogenesis preeklamsia. Kalsium sangat diperlukan untuk perkembangan normal dan menjaga fungsi tubuh. Kalsium diperlukan untuk berbagai macam proses penting seperti eksitabilitas neuron, pelepasan neurotransmitter, kontraksi otot, integritas membran dan pembekuan darah (Jain, 2010).

Rata-rata kadar kalsium darah paling pada kelompok PEB lebih rendah dibandingkan dengan kehamilan normatensi. Hasil menggambarkan semakin berat derajat preeklamsia, semakin rendah kadar kalsium darahnya. Hal ini sesuai dengan teori Sharma (2010) yang mengatakan bahwa kadar kalsium darah kelompok PEB memiliki 
kadar yang rendah, tekanan darah PER mengalami sedikit lebih tinggi daripada PEB dan pada kehamilan normotensi pada umumnya memiliki kalsium darah normal.

Berdasarkan uraian tersebut dapat dikemukakan bahwa kenaikan tekanan darah dapat terjadi karena adanya ketidakseimbangan kalsium dalam tubuh. Kalsium mempunyai fungsi dalam otot jantung yang dapat menimbulkan peningkatan kontraksi, sehingga dapat mempertahankan dan meningkatkan volume sekuncup jantung yang kemudian tekanan darah tersebut dapat dipertahankan.

\section{F. KESIMPULAN DAN SARAN Kesimpulan}

Berdasarkan hasil penelitian dan pembahasan mengenai perbedaan kadar kalsium pada ibu bersalin normatensi dengan ibu bersalin, maka dapat disimpulkan sebagai berikut:

1. Rata-rata kadar kalsium pada ibu bersalin normatensi di Ruang VK RS SMC Tasikmalaya 2018 sebesar 4.83 $\mathrm{gr} / \mathrm{dl}$

2. Rata-rata kadar kalsium pada ibu bersalin PEB di Ruang VK RS SMC Tasikmalaya 2018 sebesar $3.91 \mathrm{gr} / \mathrm{dl}$

3. Terdapat perbedaan kadar kalsium pada ibu bersalin normatensi dengan ibu bersalin PEB di Ruang VK RS SMC Tasikmalaya 2018 dengan $p$ value 0,004 .

\section{Saran}

1. Bagi Institusi Kesehatan

Hasil penelitian ini dapat menjadi masukan bagi perkembangan asuhan kebidanan dalam rangka mencegah komplikasi kebidanan dengan memberikan asupan kalsium pada ibu hamil.

2. Bagi Institusi Pendidikan

Hasil penelitian ini disarankan dapat menjadi tambahan informasi di perpustakaan yang dapat dijadikan bahan bacaan bagi mahasiswi kebidanan.
3. Bagi Peneliti lain

Sebaiknya dilakukan penelitian lain dengan meneliti faktor yang lebih luas terkait dengan konsumsi kalsium pada ibu hamil serta dampak pada persalinan dan bayi yang dilahirkan.

\section{G. DAFTAR PUSTAKA}

August P, (2012). Calcium metabolism in preeklamsia: Supplementation may help. http//www. Medscape. com. 2018

Bambang S, (2009). Struktur dan metabolisme tulang. Buku ajar ilmu penyakit ; jilid III edisi V; Balai penerbit FKUI 2009:322:2074-77

Benson, (2001). Buku Saku Obstetri dan Ginekologi. Jakarta : Buku Kedokteran EGC.

Christhoper S.K, (2012). Calcium metabolism during pregnancy and lactation. Faculty of medicineendokrinologi. University of Newfoundland, 2012:

Crhistanto, C. (2014). Kapita Selekta Kedokteran. (I, Vol. I). Jakarta: EGC.

Cunningham FG. (2010). Esensial Obstetri dan Ginekologi Edisi 21, EGC, Jakarta

Dinkes Jabar, (2017). Profil Kesehatan Jawa Barat. http://www.dinkesjabar.golid

Gonen E, (2010). Effect of pregnancy and lactation on bone mineral density and their relation to serum calcium, phosphorus, calcitonin and parathyroid hormone levels in rats. J Endocrinol Invest, 2005:28(4):322-6

Harville EW, (2013). Calcium intake during pregnancy among white and african american pregnant women in the united state. A mJ Coll, 2004:23(1):43-50

Helga (2016). Perbedaan Rerata Rasio Kalsium Magnesium Dan Rerata Rasio Natrium Kalium Serum. Bagian Obstetri dan Ginekologi Fakultas Kedokteran Universitas Andalas Padang 
Hoelman, (2015). Panduan SDGs Untuk Pemerintah Daerah (Kota dan Kabupaten) dan Pemangku Kepentingan Daerah. http://www.depkes.go.id

Hofmeyr Y, (2010). Dietary calcium supplementation for prevention of pre-eclampsia and related problem: $a$ systemic review and commentary. BJOG, 2007:114 (8):933-43

Indrawati, (2010) Panduan

Perawatan Kehamilan. Atma Media Press. Jogjakarta. Hal 57, 101

Jembawan (2015). Kadar Kalsium

Pada Preeklamsia. Bagian/SMF Obstetri Dan Ginekologi FK UNUD/RSUP Sanglah Denpasar 2015

John MF, (2009). Metabolisme kalsium. Buku ajar ilmu penyakit ; jilid III edisi V; Balai penerbit FKUI 2009: 378: 2385-401

Kemenkes, (2017). Profil Kesehatan http://www.depkes.go.lid Indonesia. Februari 2018.

Lestari (2017). Diktat praktikum. Program studi pendidikan dokter fakultas kedokteran universitas udayana

Mansjoer, (2009). Kapita Selekta Kedokteran. Aescepalus. Jakarta

Notoatmodjo (2010). Metodologi Penelitian. Teori dan Aplikasi. Rhineka Cipta. Jakarta

Perez-lopez FR, (2007). Vitamin D the secosteroid hormone and human reproduction. Gynecol endokrin, 2007:23(1):13-24

Rakhsanda A, (2012). Serum calcium level and pregnancy induced hypertensi. Dow Medical Sciences \& College, 2012:18:63-65 $\begin{array}{ccc}\text { Roszikhan (2009). } & \text { Faktor-Faktor } \\ \text { Resiko } & \text { Terjadinya } & \text { Preeklampsia } .\end{array}$

http://www.undip.ac. id

Saifuddin, (2010). Ilmu Kebidanan. Jakarta. Yayasan Bina Pustaka Sarwono Prawirohardjo. Hal 530

Siswosudarmo (2010). Obstetri Fisologi. Bagian Obstetri \& Ginekologi. FK UGM. Jogjakarta. Hal. 82

Soeriatnata (2009). Hipertensi dan Pencegahannya, dari http://www. indoskripsi, com, diakses Februari 2018

Storey M, (2008). Association of adequate intake of calcium with diet, beverage, consumption and demographic characteristic any children and adolescent. J Am Coll nutr, 2004:18-37

Sudarto, Y (2010) . Gambaran karakteristik ibu hamil resiko tinggi terhadap kejadian preeklamsia. http://www.yonokomputer.com/2011/03/

Villar J, (2011). World health organization randomized trial of calcium supplementation among low calcium intake pregnant women. AmJ Obstet Gynecol, 2006: 194:639-49

Zaini, (2009). Jurnal : Waspadi Kehamilan, Edisi I. Dari http://www.marchofdimes.com/pnhediakses Februari 2018

Zapata V, (2013). Calcium hemostasis during pregnancy and lactation in Brazilian women with low calcium intake: a longitudinal study. AmJ Clin Nutr, 2004:180(2):417-22

Zuzana A, (2008). Vascular and cellular calcium in normal and hypertensive pregnancy. Curr Clin Pharmacol, 2009: 1: 23-28 